materials, it may be that we have attained the limits of variation in this direction, and that to get something new and better we must break new ground by hybridisation or cross-breeding.

Illustrations are given in the volume before us of numerous insects and fungi which make themselves obnoxious to the fruit-grower. Some of these are the same that are too well known to us; but whether or no, the general principles of prevention or destruction are the same. We know of no work containing anything like so complete an account of these "bush fruit," and although it is mainly serviceable to American cultivators, it will also prove a veritable encyclopædia to British growers.

\section{OUR BOOK SHELF.}

L'industrie du Goudron de Houille. By George F. Jaubert. Pp. I72. (Paris: Gauthier-Villars et Fils, I 899.)

IN this book, which belongs to the "Encyclopédie scientifique des Aide-Mémoire," is given a brief account of the numerous chemical substances directly derived from coal-tar. The introduction contains a short historical account of the rise of the coal-tar industry, and this is followed by a very brief description of the methods of separation adopted for light and heavy oils, phenols, and ammonia liquor; a section being specially devoted to the nature and yield of tar formed in the preparation of coke.in Carvès ovens for metallurgical operations. The actual processes used for the separations of hydrocarbons and ammonia are very briefly sketched, no diagrams whatever being given. The remaining threefourths of the book consists of a methodical description of the properties of each of the various chemical substances the presence of which has been recognised in coal-tar or coal-gas; this description, as a rule, being unaccompanied by any account of the methods by which the particular constituent under examination has been isolated from the tar. It is, in fact, a miniature chemical dictionary with a systematic instead of an alphabetic classification. The short bibliography at the end of the book will doubtless be of some use to students.

Grundriss einer Geschichte der Naturwissenschaften. By Dr. Friedrich Dannemann. Vol. II. Die Entwicklung der Naturwissenschaften. Pp. 435. (Leipzig : W. Engelmann. London: Williams and Norgate, I898.)

THE first volume of this work was noticed in NATURE in 1896 (vol. liv. p. 316). It consisted of extracts and translations from the writings of great philosophers and investigators, and presented an attractive panorama of scientific history. The second volume has not been constructed upon the same plan, but consists of a descriptive statement of researches and discoveries which have contributed to the progress of science. Many original illustrations have been reproduced, and numerous references are given to papers which have helped to make scientific history. The volume is an interesting "entwicklungsgeschichte," and it presents the early stages in sufficient detail; but it cannot be regarded as a satisfactory statement of the modern developments of science.

Dr. Dannemann divides the history into four periods, each of which is dealt with in a separate section of the book. The first part contains a survey of the views and works of the early Greek philosophers, up to the de- struction of the Alexandrian library in 642 A.D.; the second part is concerned with the period from 642 A.D. to about the end of the fifteenth century; the third period considered extends from the time of Copernicus to the end of the eighteenth century, and includes the epochs of the foundation of modern chemistry and the discovery of the galvanic battery; and, finally, the period-" Die neueste Zeit"-continues the history to the present epoch.

It would, of course, be impossible to give anything approaching a complete account of scientific work from the early Greek philosophers to the present time in a volume of the dimensions of the one before us, and Dr. Dannemann has not attempted to do so. His volume presents a view of the investigations which laid the foundations of modern science, but it does not go further.

The work is an interesting contribution to the literature dealing with the development of the study of nature in many aspects, and as such is an inspiring volume for students of science. Perhaps the author will produce a third volume in which the advances made during this century will be described.

Practical Work in Physics. Part iv. Magnetism and Electricity. By W. G. Woollcombe, M.A. (Oxon), B.Sc. (Lond). Pp. xi + I i2. (Oxford : Clarendon Press, I899.)

THIS little volume completes Mr. Woollcombe's course of practical physics for use in schools and colleges. It is a little difficult to understand why no experiments in statical electricity are included, for some of these are valuable in accentuating principles of great importance to a student of this branch of physics. The pupil into whose hands the instructions here set down are put, must already have some theoretical knowledge of the subjects dealt with, or little benefit is likely to accrue from the performance of the experiments. It is hardly a beginner's book, for, in addition to the necessity for a modicum of preliminary acquaintance with principles, familiarity with trigonometrical ratios is taken for granted. At the same time, for the higher classes of schools of the order in which the author himself teaches, the experiments described are very suitable.

Ostwald's Klassiker der exakten Wissenschaften, Nos. 97-102. (Leipzig: Wilhelm Engelmann. London: Williams and Norgate, I898.)

THE following additions to Prof. Ostwald's comprehensive series of annotated reprints and translations of scientific classics have lately been published.

No. 97 (pp. 156) contains a translation, with facsimile illustrations, of Newton's second and third books on optics, dealing with the reflection, refraction, and colour of light, and the theory of the rainbow. The papers have been translated and edited by W. Abendroth.

No. 98 (pp. 39) is a paper "Ueber das Benzin und die Verbindungen desselben," by Eilhard Mitscherlich (1839), edited by J. Wislicenus.

Clausius's paper "Ueber die bewegende Kraft der Wärme" (1850), forms No. 99 (pp. 55), and will be of interest to all students of thermodynamics. It is edited by Dr. Max Planck. Dr. Planck also edits Kirchhoff's papers on emission and absorption of light and heat (1859-1862), printed in No. IOO (pp. 4I), and the papers read in 1858 on the mechanical theory of heat, printed in No. IOI (pp. 48). The former reprint contains a portrait of Kirchhoff as a frontispiece.

A translation of Clerk Maxwell's papers on lines of force $(186 \mathrm{I}-2)$ appears in No. IO2 ; and to the eighty-four pages, which they occupy, Prof. Boltzmann adds sixtytwo pages of notes.

$$
\text { NO. I 533, VOL. 59] }
$$

